malnutrition and disease of infants, children, and adult slaves is given in great detail. In spite of the slave owners' desire to increase the size of their black population by pronatal policies, the birth rate did not increase sufficiently to overtake the death rate. The slave hospitals on sugar plantations played an important part in the health care system; some of them were reasonably satisfactory but many more were only temporary refuges from hard labour and punishment. Despite the obstacles, some of the dedicated plantation doctors provided much needed assistance: they vaccinated against smallpox, performed surgical interventions, treated intestinal and respiratory ailments, and saved lives.

In conclusion, obviously the health of the slave population was related largely to their living conditions and the author of this well documented and fascinating study confirms that any benefits that may have resulted from medical assistance were largely negated by the harsh conditions and "vicious circle of disease and racism, whereby the debility of blacks was often misconstrued-by planters and doctors alike-as racial characteristics of laziness and shamming of illness."
Sheridan's book, which is fluent, lucid, and free of the irritating verbiage that is often met with in similar medicosocial academic theses from across the Atlantic, is one of the best studies of medical problems of slavery in the British West Indies. It is based on a wide range of historical, demographic, social, and economic sources and referenced with well over 900 notes and a copious bibliography. His transparent indictment of that period of colonisation is justified. As a historian, however, he seems to ignore the cultural environment of times past and applies present day standards and values to a period when different modes of thought and behaviour prevailed. Some of his quotations and remarks on the cruelty of racism will appear simplistic to readers who are aware that during the British industrial revolution with its "dark, satanic mills" children in Britain suffered in mines and factories from a slavery no less cruel than that on the Caribbean sugar plantations.

Doctors and Slaves. A Medical and Demographic History of Slavery in the British West Indies, 1680-1834. R B Sheridan. (Pp 442; figs; £25.) Cambridge University Press. 1985. ISBN 0-521-259657.

\title{
Magic, myths, madams—and medicine
}

\author{
ALEX PATON
}

"Doctors who are good raconteurs make wonderful reading," wrote Cyril Connolly about this fascinating book on its first appearance in 1955. For reasons that he prefers not to make too clear but connected with the displeasure of King Emmanuel Victor III of Italy, Alberto Denti (later the Duke of Pirajno) was posted together with the Tall Young Man (a cousin of the king and later Duke of Aosta) and two others to a remote colonial station on the coast of north Africa. He spent 18 years of "inestimable satisfaction" practising medicine and carrying out cloak and dagger intelligence operations among the tribes who inhabited the vast spaces of Tripolitania, Eritrea, and Ethiopia. His love affair with the region and its people ended ignominously when, as governor of Tripoli, he was forced to hand over the city to Montgomery.

The duke's patients were a motley collection of tribesmen, sailors, merchants, prostitutes, criminals, and others. They were superstitious and believed in spells and evil spirits; he recounts some of the delightful myths associated with these. Strangely they had a great respect for medicines, which they believed had magical powers, and particularly for scalpels and syringes. The doctor soon gained their confidence with his seemingly miraculous cures, especially among the tribal chiefs and their families, where diseases such as typhoid and syphilis were rife. Many are the memorable characters described with affection and a great deal of humour; Bughesa el keddäb (the liar); the boy who chased shadows; the importunate Abyssinian ras (prince), who admired the doctor's appetite; the filthy louse ridden Tuaregs who were so graceful and aristocratic, and above all the women, who are portrayed in loving detail that shocked some people when the book was first published.

And the stories - they might have come out of the Arabian Nights. Haj Ahmed es-Sed, the wealthy merchant who had made the pilgrimage to Mecca, complained that a serpent in his stomach was causing such pain that he could not go on living; it would be unfair to give away the secret of the cure which gives the book its title. The elderly Tuareg woman Damesa suddenly startled the doctor when he was examining her in a desert tent by speaking perfect French, and then told him the story of her extraordinary life in Algeria. Rebecca Buaron, the madam of the Misurata brothel, and her girls provided sumptuous dinners for the duke that he not only enjoyed eating - the more highly spiced the food the betterbut describing. But undoubtedly the most exciting tale is the tracking of $e l$ wähido (the solitary one), a wounded elephant with a party of armed men looking for rebels for what seems to have been at least three weeks during which they came near to death from floods

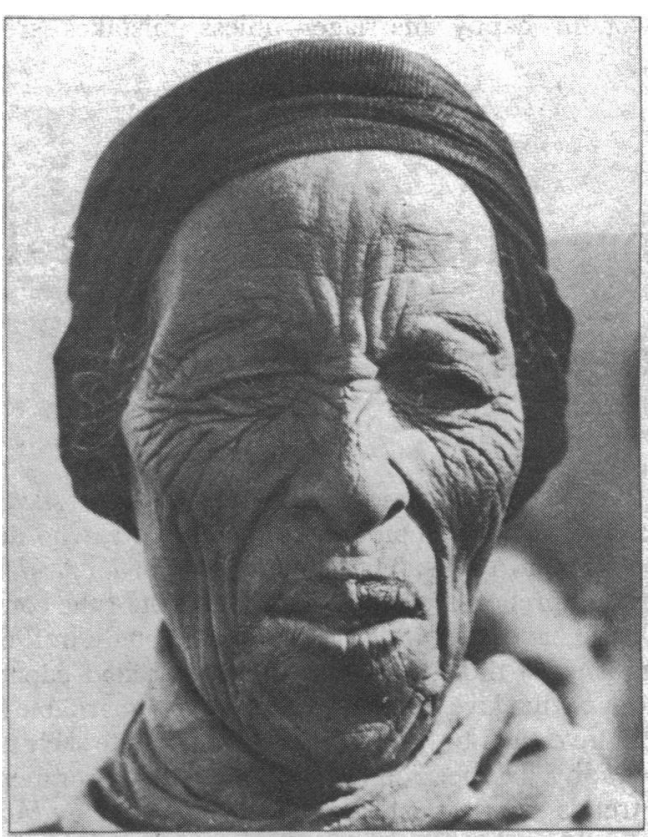

Woman from the Ogaden.

and starvation. And the most extraordinary is that of the lion cub, Neghesti, which adopted him after he had set its broken leg and became so attached that his servants were convinced she was the incarnation of his mother.

The audience for travel books is said to be at an all time high; Century Travellers and Eland, publishers of the present volume, produce some of the best of the genre in elegant, inexpensive paperbacks. The Duke of Pirajno is a story teller in the classic mould, and Dervla Murphy, another of my favourite travel writers, provides an additional bonus with her sympathetic preface.

A Cure for Serpents. An Italian doctor in North Africa. The Duke of Pirajno. (Pp 264; figs; $£ 4.95$ paperback.) Eland Books. 1985. ISBN 0-907871-16-X. 